\title{
Nuovomondo, Ellis Island, and Italian Immigrants: A New Appraisal by Emanuele Crialese
}

\section{Marie-Christine Michaud}

Abstract: Ellis Island remains in the American collective consciousness a centre of immigration where thousands of Europeans who expected to enter the United States between 1892 and 1954, went through. As such, Ellis Island was a symbolic bridge between the Old World and the New.

It is the vision of this bridge, or rather a no man's land between the two worlds that Emanuele Crialese wants to give of Ellis Island in his movie Nuovomondo (Golden Door in the international version). It deals with the journey to America of a Sicilian family at the beginning of the 20th century. It is divided into three parts, one in Sicily dealing with the departure; the second one is the journey on the ship; the third one extensively deals with the arrival on Ellis Island.

The film is rather realistic in the sense that it is widely based upon archival material, which becomes apparent when comparing photographs taken at the turn of the century and the scenes from the movie taking place in Ellis Island. By being realistic Crialese first associates Ellis Island to an alienating island, a devilish place where immigrants experienced trauma and humiliation, even possible deportation. The study of the staging reveals that the place is often seen as a prison and that it is linked to confusion and misunderstanding between the immigrants, their dreams and the requirements of the American immigration officers. Nevertheless, the movie is optimistic and displays a hopeful image of Ellis Island. The main characters manage to be admitted in America then seen as a Promised Land. But, the United States is never presented in the film, which provides a feeling of unreachability, as if Emanuele Crialese had wanted to challenge the myth of "il Nuovomondo" as a Promised Land.

Today, Ellis Island is a museum of immigration and a tourist attraction in the port of New York City. But, for the thousands of Europeans who expected to enter the 
United States between 1892 and 1954, for those "who yearned to breathe free" (as Emma Lazarus wrote in her poem called The New Colossus, which is engraved on the plinth of the Statue of Liberty), it was a centre of examination where they passed tests to check their eligibility to immigrate to the United States. As such, Ellis Island was a symbolic bridge between the Old World and the New.

In Nuovomondo (Golden Door in the international version), Emanuele Crialese wants to give an unprecedented and qualified image of this centre, both hopeful and cautionary. The 2006 film deals with the journey of a Sicilian family, headed by Salvatore Mancuso (Vincenzo Amato), from their village to Ellis Island. The film is divided into three parts: the first occurs in Sicily, when the Mancusos leave their village and get ready to cross the ocean; the second one features the journey on the ship; the third one deals with the arrival on Ellis Island. Crialese's representation of Ellis Island from the point of view of Italian migrants at the beginning of the twentieth century is torn between hope and fear. It displays confusion and misunderstanding, but it is also based upon dreams of a better future. Indeed, the director's vision of Ellis Island is both a devilish place where candidates for immigration could be humiliated and a "golden door" to the New World.

\section{The historical background}

No date is specified to situate the action of Nuovomondo-even if Crialese acknowledged that he considered that the action took place in $1904 .{ }^{1}$ The audience can suppose it takes place between 1901 (as the first building, which opened in 1892, was damaged in a fire in 1897 and re-opened in 1901) and 1917, when the Literacy Act stipulated that, in order to be entitled to enter the United States, one had to be able to read and write in any language. Salvatore Mancuso, the main character of the film, revealed that he could neither read nor write. He is nevertheless accepted to immigrate to the United States.

The new buildings (Figure 1) ${ }^{2}$ were reported by The New York Times to be "magnificent and admirably arranged" ("New Immigration Station"), and this

\footnotetext{
${ }^{1}$ See https://www.youtube.com/watch?v=v90thqbuu8c (accessed on 16 Feb. 2017).

${ }^{2}$ Two types of figures are presented in this essay: photographs from the turn of the century, depicting reality, taken from Pamela Reeves's and Lidio Tomasi's books, and screengrabs from the movie. The comparison between these two types of images will show that Nuovomondo has a strong realistic dimension.
} 
newspaper underscored the space available and the arrangement of the different quarters, each devoted to a special purpose: a place for medical or administrative inspections, dormitories, a bathing house, a hospital, and a restaurant. It seemed that there were efforts to facilitate the reception of the newcomers, the fluidity of the checking process, and the respect of the immigration legislation.

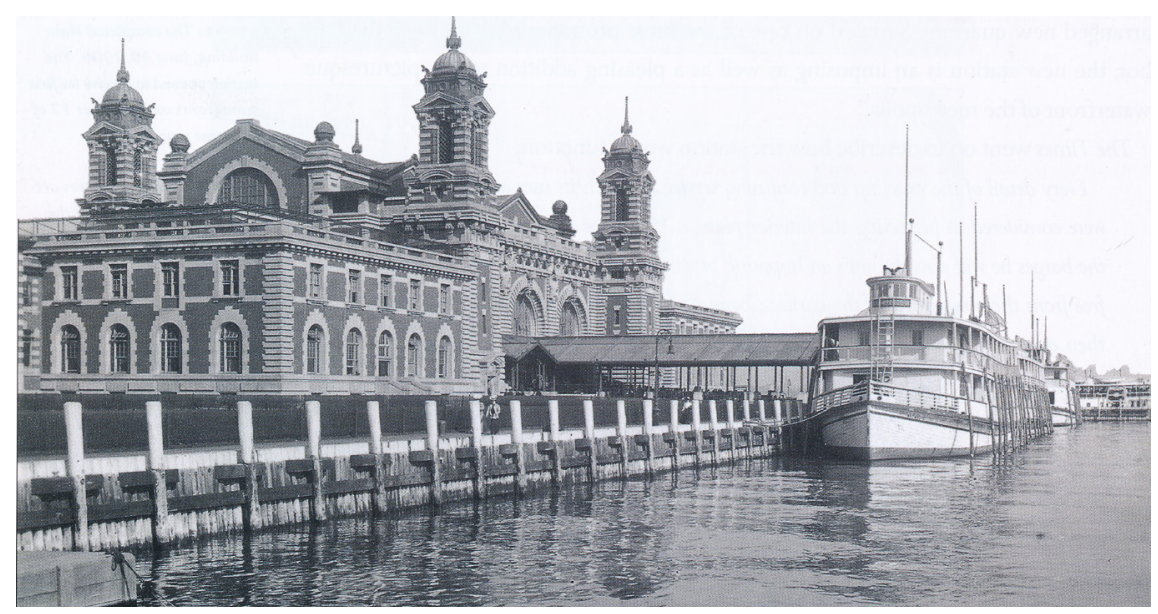

Figure 1. Source: Reeves 40

This new centre of immigration aimed at receiving the thousands of Europeans who decided to go to the United States at the turn of the century. Immigration officers had to make sure that the newcomers would not be a public charge, were in good health, and were "good enough" to be admitted into the country. The previous centre, Castle Garden, became too small as massive waves of Europeans came and had to be processed. Some 4.5 million Italians came to the United States between 1880 and 1920; 98 percent of them were processed through Ellis Island, which was the main harbour of disembarkation in the United States. There, immigration applicants had to go through an administrative process and undergo psychological and medical tests. Since many of them were not used to displaying identity documents or having their health checked, their experience on Ellis Island represented an ordeal. The stakes were very high, because the fulfillment of their project to immigrate to the United States or their rejection would be decided during their processing in this centre. This is the focus of Nuovomondo. 
On Ellis Island, some 5,000 individuals could be processed in a single day, and tests could last between one hour and four hours. Those who were less lucky could be detained on the island for several days, even weeks, in the case of health or administrative problems (Mangione and Morreale 111). After several weeks of travelling from their village to the New York harbour, newcomers were exhausted and confused and feared that their acceptability could be challenged. In addition, since the 1880s, some laws had been adopted to bar the entrance of some applicants: contract labourers, prostitutes, paupers, convicts, people infected by contagious diseases, and mentally ill people were rejected. As the list kept growing (for example, in 1903, anarchists became inadmissible also), immigrants' fear to be refused entry increased accordingly. In reality, only a small number of newcomers were eventually prevented from entering the country. Eighty percent of the immigrants went through the tests without any problems and could enter the United States without any delay; the other 20 percent could be detained on Ellis Island for a few days for further examination, and only two percent of them were actually sent back home (Kraut 59). Deportation was rare, but some days of detention were common.

In the European harbours where their passage had originated, the aspiring immigrants were checked according to United States regulations. Moreover, the ship companies were held responsible for their passengers: if applicants were rejected, the companies had to pay for their return trip. Hence, European harbours (Naples and Palermo, as far as Southern Italians were concerned) imposed passenger checks and, by the time the ship arrived at Ellis Island, information about the applicants was already collected on ship manifests and given to Ellis Island officers. What took place at Ellis Island was a sort of secondary check, which may explain the small amount of deportations. The other explanation comes from the fact that first-generation immigrants were often young adults, ready to get any job in the New World. They had to be in good shape to work and, as a consequence, they were strong enough to bear the hardship of travel and pass the tests successfully.

In any case, immigrants associated feelings of alienation with Ellis Island. A loss of identity could result from the processing, since some names of newcomers, hard to read and pronounce for the American officers, could be changed to sound more familiar. For example, an Italian surname like Randazzese could be shortened to Randa (Mangione and Morreale 117). Even if one considered these changes as a myth more than a reality (since the immigrants' names were already written on the 
ship lists that were given to immigration officers on Ellis Island), ${ }^{3}$ the idea that the process was alienating was widely spread among would-be immigrants in Europe, which made the passage to Ellis Island all the more frightening. Indeed, it was the last step that immigrants had to endure, which explains its important place in the film. Golden Door, the title for the international version of the film, places a special significance onto Ellis Island: it was the door to the New World. But the immigrants' apprehension was such that the examination centre represented a final step per se, even if the travel to their destination was not necessarily over yet.

Female immigrants especially underwent strict checks: the American government wished to avoid the coming of prostitutes and women who could not make a living, fearing that they would either become public charges or resort to prostitution. This is the reason why, generally speaking, among Southern- and Eastern-European migrant flows, unaccompanied women were expected to be sponsored by relatives, friends, or fiancés who would fetch them upon their arrival. Among the Italians, sponsorship and accompaniment were also due to the importance of the social family structure as well as the dangers that travelling on one's own could represent for women. In the film, the experience of women is given special attention, which is rather unusual, since unaccompanied women, and Southern-Italian or Sicilian women in particular, were not so numerous as travellers; as a result, not many historical analyses extensively deal with this issue. In a way, Crialese pays them tribute while denouncing the alienation that immigrants experienced on the island.

Nuovomondo displays a realistic vision of Ellis Island, in the sense that it is widely based upon archival material, which becomes apparent when comparing photographs taken at the turn of the century and scenes from the movie. It also relies upon a positive, even dreamlike and romantic image of the centre of immigration. In alternating scenes that deal with the intimacy of men and women with ones portraying medical tests and administrative processes, the film achieves a warmth that goes beyond historical testimony; rather, the movement back and forth between the characters' intimacy and the masses of newcomers highlights the stressful confusion related to the never-ending inspection process. But, in addition to a feeling of misunderstanding and confusion, the alternation of scenes also gives a sense of rapidity. After a long journey across the ocean, which took

\footnotetext{
${ }^{3}$ These changes of names were not so numerous, which testifies that it was more a myth than reality. See Carnevale 84-85.
} 
more than a week at that time, everything could go very quickly, precipitating the admission to the New World after an endless wait.

\section{Ellis Island, an alienating world}

As a whole, the conditions of reception on Ellis Island were expected to be terrible. People were treated like cattle (Brownstone 15). Harassment, contempt, and abuse characterized the process. For example, in 1901, scandals erupted concerning bribery and corruption among immigration officers, which led to the nomination of a new commissioner (Reeves 43-44). This is why the movie presents immigrants in masses, to convey the idea of their anonymity and loss of individuality when facing immigration officers who did not pay attention to the immigrants' personal situations. Hence immigrants are often presented in a high-angle shot (when they get into the Great Hall, and when they cross the alleys and go from one room to another) to emphasize their vulnerability and confusion (Figure 2). They are overwhelmed by their fate. They have to obey the orders of the Immigration Service officers if they want to have a chance to be admitted to the United States.

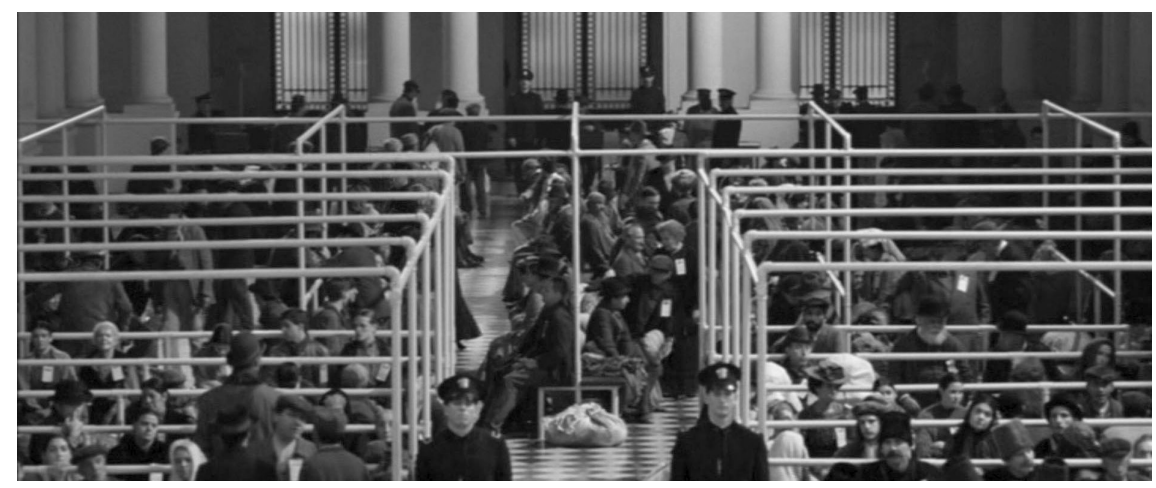

Figure 2. Courtesy of Memento Films

Thus, the centre was nicknamed "the Island of Tears," and the New World as a whole inspired fear in the newcomers in spite of their dreams. ${ }^{4}$

\footnotetext{
${ }^{4}$ See, for instance, Brownstone 147 and Kraut 62.
} 
Confusion concerning the behaviour that one had to adopt, especially with regards to how to answer the questions posed by the immigration officers, made the experience stressful. The applicants were disoriented by these questions because they did not always understand them. Mutual-aid and immigration societies such as the Hebrew Immigrant Aid Society (HIAS), the Society for the Protection of Italian Immigrants, and the St. Raphael Society provided interpreters and social workers to help them, but the meaning of the questions could remain obscure because of differences in cultural backgrounds between officers and applicants (La Guardia 67-71). A revealing example is given in Nuovomondo when an Immigration Service officer asks how many legs "make a cow and a hen.” Instead of answering the number of legs (six altogether: four for the cow and two for the hen), the newcomer answers that "they walk," though he is given a translation of the question. Immigrants did not know what was expected from them.

To emphasize the image of confusion, the director uses close-up shots when applicants must answer questions. This framing contrasts with the wide shots that show immigrants in masses while they line up to enter the centre, or when they arrive in the Great Hall. Though immigration was a collective phenomenon (here, a family project), fates were individual and each applicant was alone in front of the Ellis Island officers. Even if the journey was organized through families' or acquaintances' networks, each immigrant had to face tests on his or her own and could be separated from fellow travellers or relatives if his or her answers did not meet the requirements. At the end of Nuovomondo, immigration officers feel no remorse for sending Salvatore Mancuso's mother, old Fortunata, back to Sicily, while the other members of the family are allowed to enter the United States.

In a different scene, the film also underlines how the officers' logic did not correspond to the kind of real lives the immigrants led. To check the mental health of Pietro, Salvatore's youngest son, one officer proposes an "exercise" and asks him to open a door and put a chair next to it. Although this seems simple, useless, and meaningless to Pietro, he complies. The order becomes even more deeply incomprehensible to Pietro when he sees that the door opens onto a wall (Figure 3). 


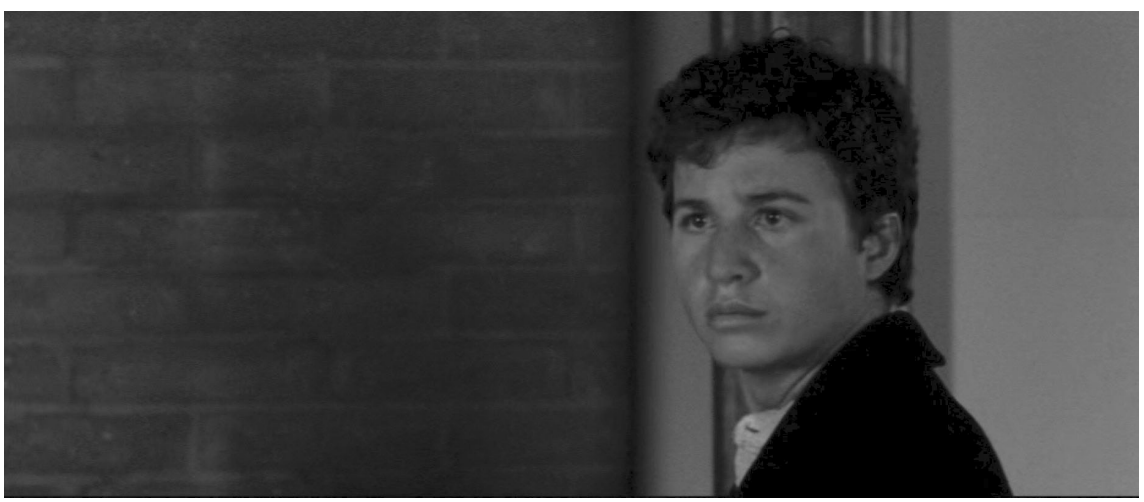

Figure 3. Courtesy of Memento Films

Another source of confusion came from the complexity of the administrative requirements. However, the film does not emphasize them, as if the director wanted to underline the American authorities' reliance on physical tests and, above all, intellectual tests to see if newcomers were clever enough to be accepted. This choice stresses the personal and intimate nature of the traumatic experience of Ellis Island. One of the characters in the film, Lucy, a young English lady played by Charlotte Gainsbourg, qualifies this process as "a modern vision": the ironic tone of her statement, uttered in a close-up, reveals Crialese's criticism of this selective process. It may refer to the pseudo-scientific theories such as eugenics that had spread since the end of the nineteenth century and led to the enforcement of IQ tests to appraise the ability of foreigners to enter the United States. The lack of administrative details concerning the laws or the entry-tax that candidates had to pay, as well as the lack of a date in the film, tend to draw the audience's attention to the inner experience and the anguish that the physical and mental health tests constituted for immigrants.

\section{Ellis Island, a No Man's Land}

The actual arrival of the immigrants to the island is not shown in the film. When their ship reaches the port of New York City, nothing can be seen because of the fog. The destination of the journey is the New World, but it remains out of the frame, which makes the process on Ellis Island more meaningful and fearful for travellers. At the same time, this omission spurs the imagination of both the 
characters/immigrants and the audience; it is also a way for the director to show that Ellis Island, though an island belonging to the city of New York, was a kind of no man's land. Immigrants were no longer in their countries of origin but not yet in America, and to get to Ellis Island did not mean that one was allowed to enter the United States.

Later in the film, when immigrants have gone through the tests and are getting closer to the final destination, they are staring at the Lower Manhattan skyline through a large window, but New York City remains out of the frame. The characters can see it, but the audience cannot. The unreachability of the Promised Land is implied; they are not in the New World yet. In addition, the window is a diagonal rib window like those in churches built according to Gothic architectural lines (Figure 4). Is this a promising signal? Does it allude to the United States as a nation whose foundation was inspired by the Scriptures? Can we say that Ellis Island is a front door to heaven on earth because of the window that looks like a stained-glass rose window? Ironically, the men climbing up the window and talking about the high buildings that can be seen in Manhattan and about the elevators recall the previous waves of immigrants-Italians and other men coming from Central and Southern Europe-who built the skyscrapers of modern American cities. The impossibility to see outside the centre locates Ellis Island out of space: it is depicted as a confined environment that newcomers are eager to leave, as if it were a prison, which is a recurrent theme in the film.

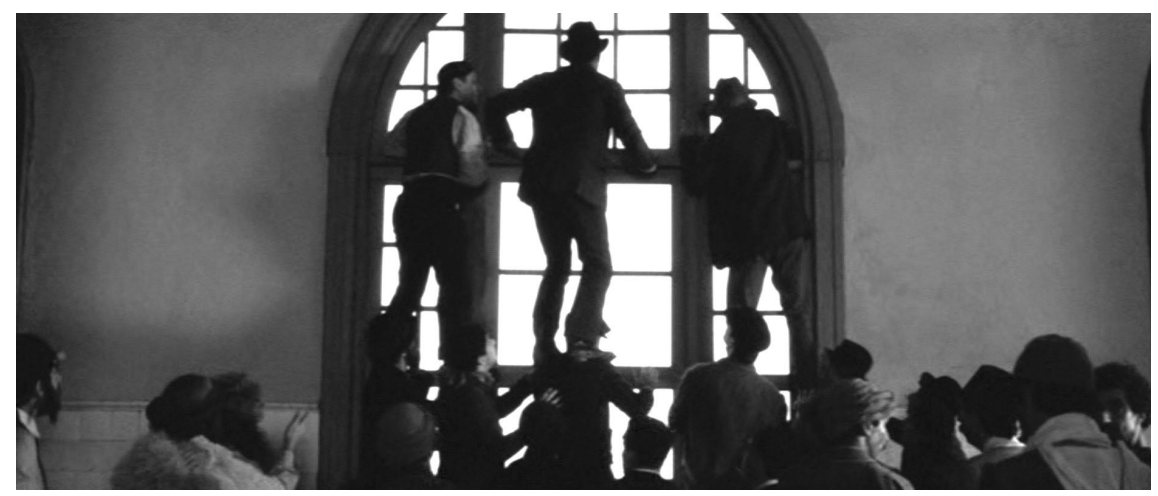

Figure 4. Courtesy of Memento Films 
The first scene that takes place on Ellis Island presents newcomers in a line, along the wall of the main building, which emphasizes the actions of queuing and waiting (Figures 5 and 6). This introduction of the theme of waiting is realistic, as the picture below taken from the turn of the century confirms (Figure 5). Though the process may not have been long, as is the case for the Mancuso family, the representation of the time spent in the centre gives a feeling of slowness and length.

The first floor of the main building was occupied by baggage-storage facilities, a railroad ticket office, a waiting room, and food counters; the administrative offices were on the mezzanine level. The second floor comprised the Great Hall, also called the registry room, and the inspection offices: this is where the newcomers' ability to enter the United States was controlled. The medical examination began as immigration candidates climbed the stairs to the second floor; in fact, it started even in European ports where American physicians, or local doctors selected by American consuls, examined candidates for emigration and could reject them, which constituted an initial source of fear (Kraut 47; Daniels 273).

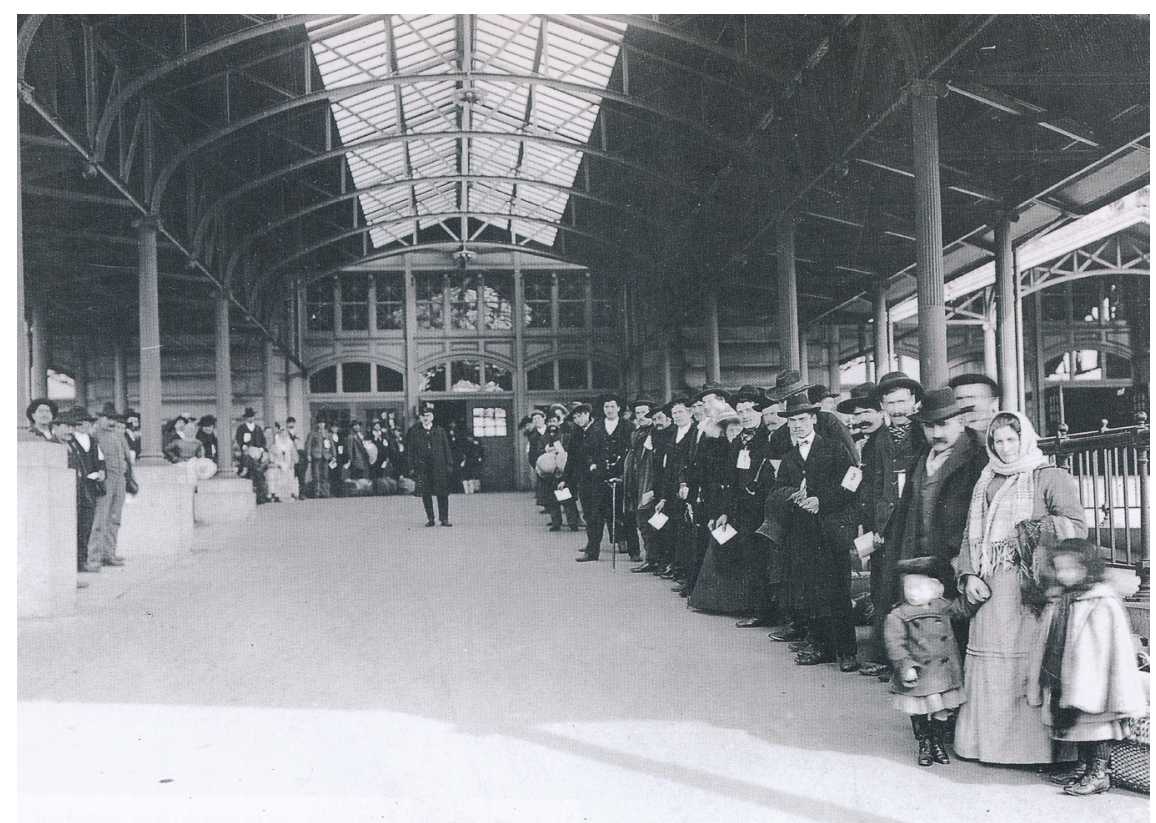

Figure 5. Source: Reeves 72 


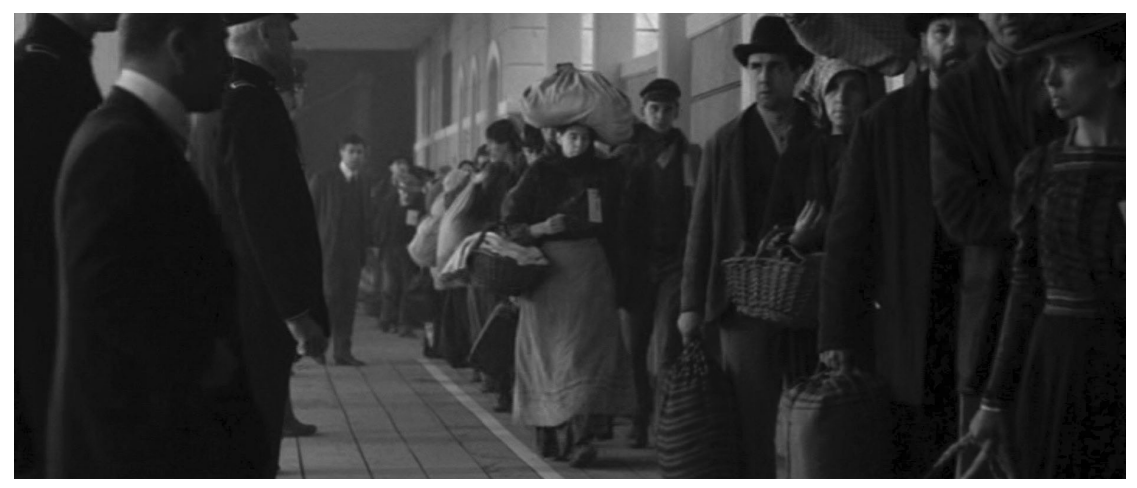

Figure 6. Courtesy of Memento Films

The eye inspection was particularly dreaded. The physicians verified if immigrants were affected by trachoma, a widespread disease at that time. Applicants were afraid of this medical inspection not only because it was painful, but also because contagious diseases, such as trachoma, would automatically prevent them from being granted entry into the country, as Fiorello La Guardia recalls:

Many immigrants were found to be suffering from trachoma, and their exclusion was mandatory. It was harrowing to see families separated. [...] Sometimes if it was a young child who suffered from trachoma, one of the parents had to return to the native country with the rejected member of the family. When they learned their fate they were stunned. They had never felt ill. They could see all right, and they had no home to return to. (La Guardia 64-65)

Those who were suspected of health problems received a chalk mark on the breast of their clothing, which is what happens to Fortunata in the film (Figure 7): the letter B indicated a back problem, X signified a mental deficiency, CT meant trachoma, and L stood for lameness. Fifty percent of the immigrants with a chalk mark were re-examined to see if they should be deported or treated in the hospital (which was located in a different building on the same island) before they could enter the country. If no medical problems were detected, the newcomers were taken to the immigration inspection, where their identity, motives, and financial resources were checked. 


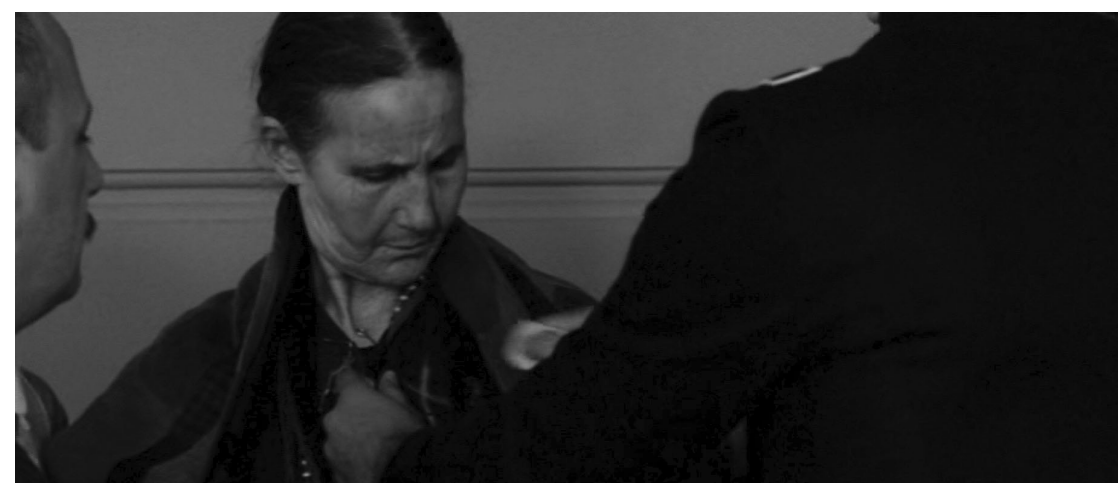

Figure 7. Courtesy of Memento Films

The medical inspection was a great source of apprehension because it was something new for the immigrants coming from Southern-European villages; as long as they could live and work, they did not really pay attention to their health. In addition, the inspection represented a crucial step in the process of immigration. This is what Nuovomondo suggests by insisting on the minutiae of the inspection in numerous scenes. Two episodes are noteworthy: the medical examination of Salvatore and his two sons and the gynecological visit of female applicants.

Male immigrants stood naked in front of physicians, which was humiliating experience. In the film, Pietro is reluctant to take off his pants, which makes the physician suspicious, so the physician asks him more questions. Salvatore interferes, as he wishes for his sons to be docile to make sure that they will enter the United States. According to him, what is important is the fact that Pietro is a good worker; for the physicians, the examination of the intimate parts of the patient's body is necessary. Revealingly, the shot's closeness emphasizes Salvatore and Pietro's lack of understanding and their efforts to explain Pietro's behaviour. The framing heightens the scene's tension, and Pietro is taken aside for further examination.

Meanwhile, the women were checked for lice and submitted to gynecological examinations, as venereal diseases constituted a criterion for exclusion (Figures 8 and 9). Fortunata opposes such a medical test, refusing to be touched in her intimate parts; this is a supplementary element to show the cultural shock that immigrants might experience upon arriving in the New World. She does not obey the officers' orders and is eventually denied access to the United States. 
In fact, as an old woman coming from a Sicilian village, she had set out on the journey only to follow Salvatore. In reality, she does not want to emigrate, so she makes no effort to comply. The movie alludes to the generational differences in attitudes regarding emigration. For the old generation, going to the New World does not inspire hope for the future, as their lives remain in their village; however, the younger adults comprising the vast majority of immigrants (some 70 percent before the First World War, according to the Census Bureau), and embodied here in the character of Salvatore contemplate starting a new existence in a land where they can work and raise a family.

These scenes present medical examinations as interferences on individuals' intimacy, a way to look at immigration candidates with contempt, or even a way to impose an inferior status on them. The scenes emphasize the humiliation that immigrants felt when they became acquainted with the practices of the host society.

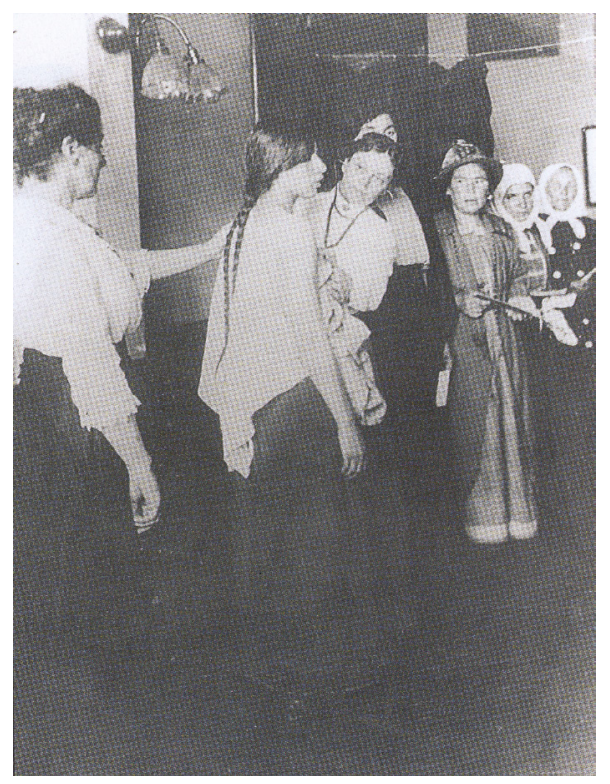

Figure 8. Source: Reeves 59 


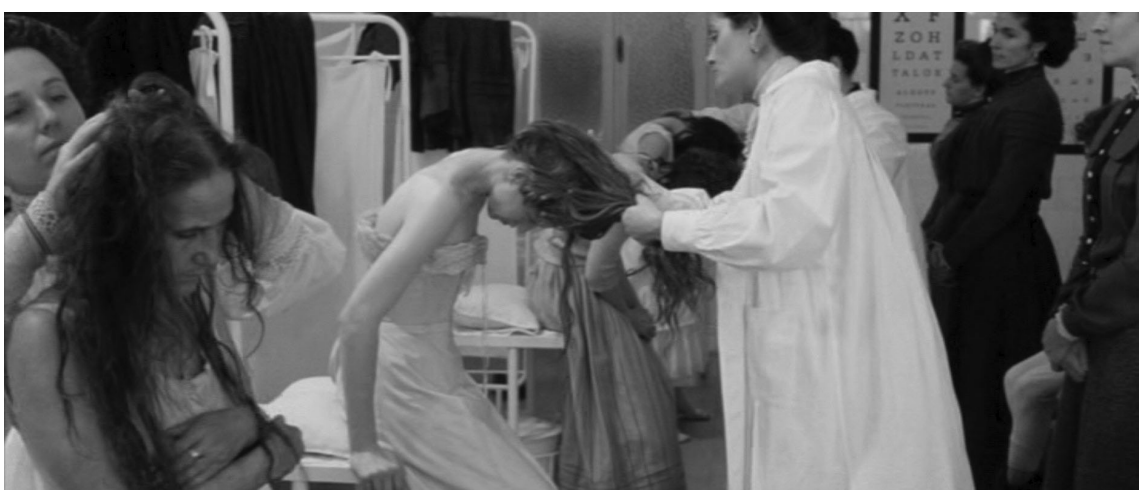

Figure 9. Courtesy of Memento Films

Nuovomondo shows how immigration candidates were intimidated as soon as they arrived on Ellis Island. One of the main elements used by Crialese to represent their fears is the extensive use of iron railings (Figures 10 and 11). There are bars in so many places within the centre that the newcomers seem to be in a prison. Reality and the fictional representation given by Crialese coincide, since, in the Great Hall, "there was a maze of bars, high wire pens, walkways and locked gates, along with uniformed guards and inspectors. America waited on the other side" (Brownstone 14). Between each examination, immigrants could wait on benches, in the Great Hall, or in queues until they were called upon in groups or one by one.

The railings were supposed to facilitate the processing and lining up of newcomers, but they also made the place look like a prison, which reinforces the image of confinement, of cattle processing, which turns the passage through Ellis Island into a traumatic experience. There are vertical and horizontal lines in nearly all the rooms in the centre: bars on the beds, in the dormitories, and in the hospital; tiles on the floor; windowpanes; all this accumulates to a sensory experience of reclusion. Bars and grids appear so often that the audience is bound to compare Ellis Island to a detention centre. 


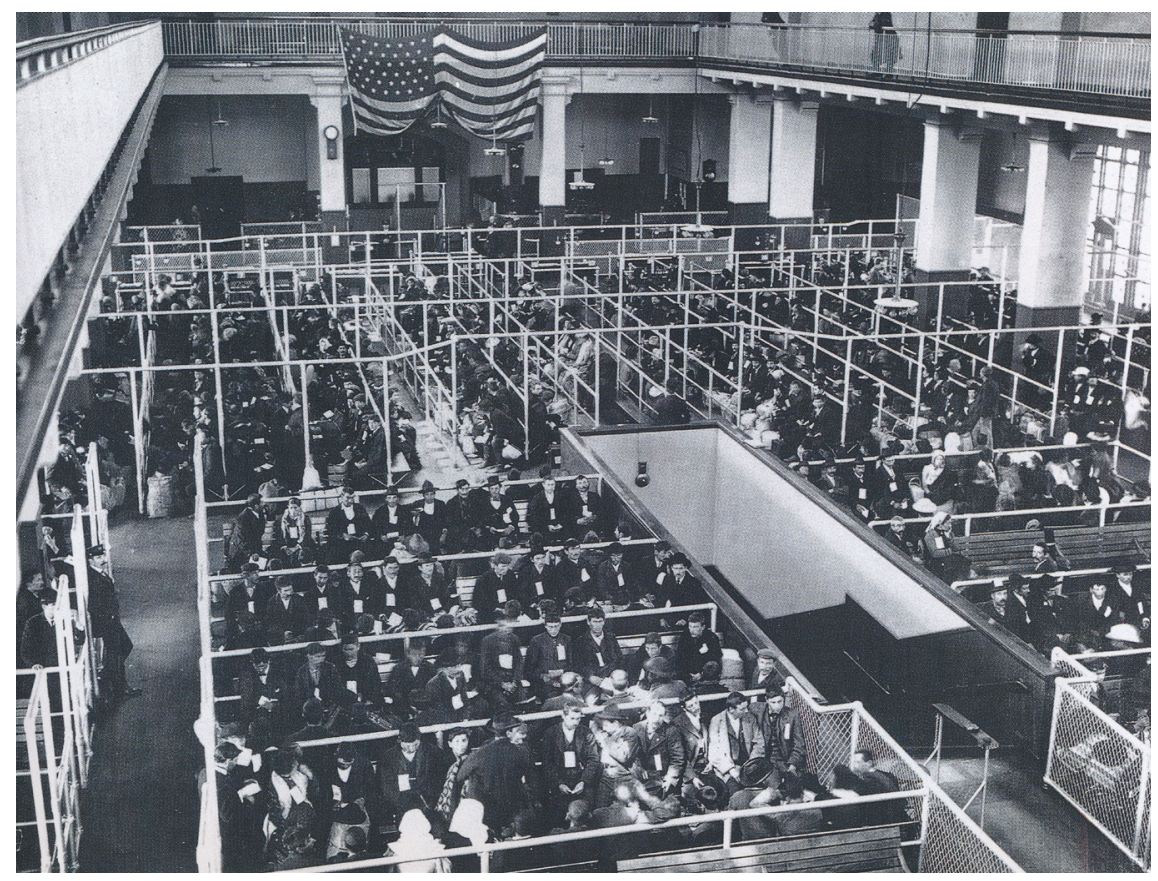

Figure 10. Courtesy of New York Public Library

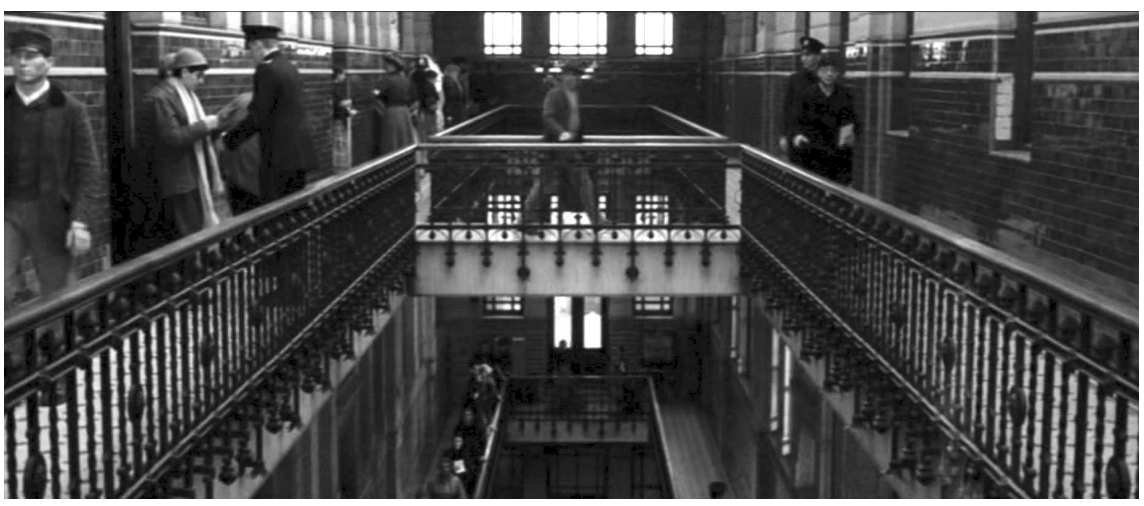

Figure 11. Courtesy of Memento Films

In his seminal book Surveiller et punir, Michel Foucault argues that modern prisons as enclosed spaces deprive even more detainees of their liberties as they 
are hidden from the public sphere and people. The architectural model, with bars that mean isolation and windows that open not on open-air areas but on inner yards, imposes a strict restraint, the aim of which is eventually to make individuals into uniform, docile bodies, and have them fit into the mould of outer society. In the film, Foucault's statement may apply to the way the structure of the main building is presented. The architectural model symbolizes the difficulties that the migrants go through to be allowed to enter the United States—almost suggesting that freedom was difficult to reach in the host country. The normative process of the tests to which the migrants are subjected is supposed to permit the entrance of only the individuals who are likely to follow the American model, that is to say to assimilate. Those who fail the tests are deported. Thus, Ellis Island appears to be more of a golden cage than a golden door.

One scene in particular calls attention to this visual analogy: immigrants are so eager to discover New York City that they climb up the large front diagonal rib window to gaze at the modern metropolis with its tall buildings (Figure 4). The shot is close and the screen is nearly completely occupied by the window with its little square panes, which is a copy of the original window in the main building of Ellis Island (Figure 12). The window represents hope, as it is facing Manhattan, the Promised Land, on the right of the screen, and, according to the artistic codes, what is facing the right is turned toward the future; at the same time, however, it is crossed by panes which stand for bars, preventing access to the outside world. This visual device makes Ellis Island appear like an enclosed, limited, suffocating space (Figure 13). Indeed, as soon as the characters enter the building, the film remains within the boundaries of the centre, a strong contrast with the open space in the scenes depicting the crossing of the Atlantic Ocean.

The symbolic significance of the window and of the bewildered migrants' looks can be explained by an analysis of the presentation of spaces: the twentieth century is an epoch of juxtaposition, of simultaneity; the near and far can go together or they can oppose one another. ${ }^{5}$ In the film, the enclosed space of Ellis Island and the allegedly open, free space of America are placed side by side, underscoring the contrast between expectation and reality. This presentation reaffirms the idea that Ellis Island is a no man's land, a sort of prison where individuals must follow the rules before experiencing freedom.

\footnotetext{
${ }^{5}$ See Foucault, Surveiller et punir.
} 


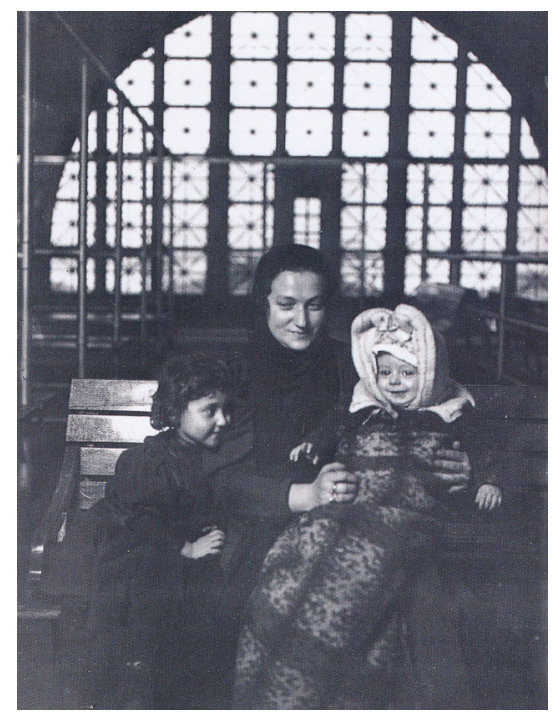

Figure 12. Source: Reeves 70

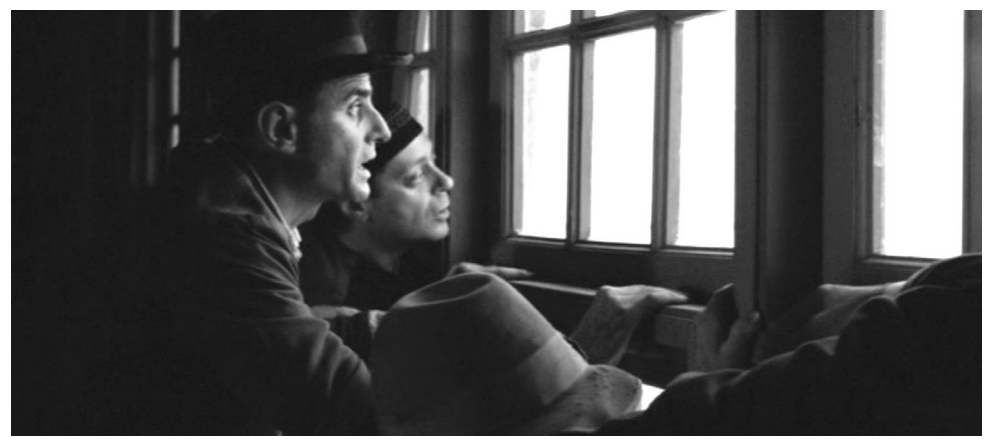

Figure 13. Courtesy of Memento Films (see also Figure 4)

The representation of imprisonment, in this space as well as in the immigrants' inescapable fate, is reinforced by the long scenes concerning marriages that were arranged, confirmed, and celebrated on Ellis Island. The consternation of young women can be felt through their desperate looks when they discover who their future husbands are. These scenes are repeated eight times, the final one announcing Salvatore's wedding with Lucy, a young English woman whom he had met when he boarded the ship and with whom he had fallen in love. For 
Salvatore, marriage amounts to hope since he loves Lucy; for her, it is a promise for a better life even if she does not love Salvatore. The audience understands that she had been denied access to the United States before, and then she is ready to marry Salvatore, a poor Sicilian, because he represents the promises of the New World. According to Salvatore, love will come later (Michaud 37-50). Crialese insists on the process as a way to reveal that women were driven to marry even unknown men in order to be able to immigrate into the United States. It displays despair and hope at the same time because these husbands stand for a better social status but in some cases their social position, physical appearance, or old age were a great disappointment for the young women.

Arranged marriages were then commonplace in Southern and Eastern Europe (Baily 152; Messina 191). The massive migration flow at the end of the nineteenth century was mainly composed of young adults who came to the United States to find work, and the shortage of women in ethnic colonies made them send home for brides. As a consequence, many of the women who travelled on their own were brides-to-be and had their weddings arranged by their parents, who wanted to offer their daughters a better future and, in many cases, benefit from remittances (Cinel 65-69). This is what Nuovomondo pinpoints, since several young women in the film have no other choice than to accept the men in front of them as husbands unless they are ready to return to Europe. The arranged weddings are frightening. The lack of movement in these scenes, the surrounding silence, the fixed shot make the atmosphere tense and express the young women's misery: the shot frames the women frontally, as they face the camera, while only the backs of the men's heads are visible in the foreground (Figure 14). The men are presented as anonymous figures, which underlines the fear among the women. The men seem to be attending a beauty contest or choosing their favourite item in a market place. Such a scene presents the women as having inferior status, like animals or any object in stalls, which reveals the small value that they were given in the social spectrum of migrants at the turn of the century: it appears that they could be selected, purchased, or even rejected. This situation reinforces their vulnerability and exploitability. The women's consternation goes deeper still, as they have dressed up for their future husbands, as tradition dictates, but the "fake" celebration turns into disillusion. This situation was part and parcel of the immigration project, and it was the price to pay to come to the New World. 


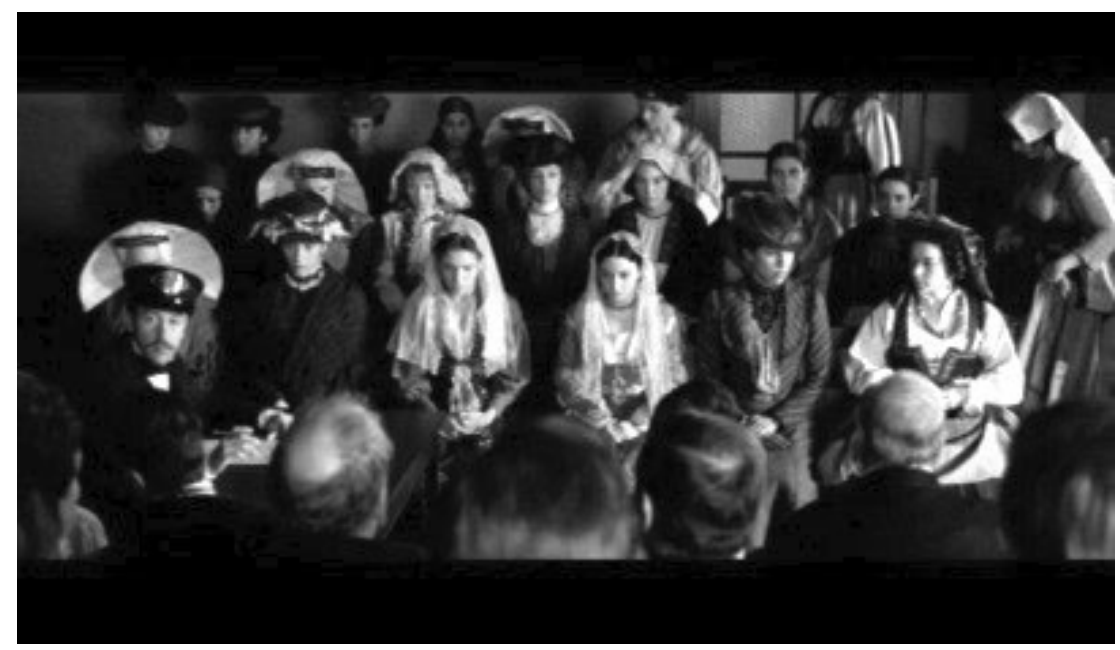

Figure 14. Courtesy of Memento Films

Through the realism of these scenes, Crialese denounces the conditions that women had to face to be able to enter the United States, since unaccompanied women were looked at with suspicion, for fear that they would become public charges or prostitutes. The solution to their acceptance in the Promised Land was to find a husband. The historiography on immigrant women relies mainly on testimonies, and the fact that the film's director wants to call so much attention to the women's fate is relevant to the message that he delivers concerning the trauma that emigration represented. ${ }^{6}$ Nevertheless, Crialese's message is a hopeful one, as the happy ending and the titles, Nuovomondo or Golden Door, suggest.

\section{Ellis Island, a golden door}

Nuovomondo does not show the whole process of inspection and admission to the United States precisely or chronologically. Its purpose is rather to display a representation of what the centre stood for in the immigrants' minds. The framing and direction are instrumental in portraying Ellis Island as a golden door at the end of a perilous mental and physical journey.

\footnotetext{
${ }^{6}$ See, for instance, Donna Gabaccia’s volume Women, Gender, and Transnational Lives; Messina 186-202.
} 
Most of the Mancuso family members manage to pass the tests. They correctly answer the questions and are all admitted to the New World, except old Fortunata, who is reluctant to emigrate and does not want to submit to the American way of thinking. She rebels against the tests and the officers' investigation as if it were too late for her to give up la via vecchia, the traditional Italian way of living. She stands as a spokeswoman for her generation which refuses to comply for the sake of gaining entry. She is wary about the questions that the immigration officers ask and about the Americans' ability to evaluate the foreigners' worth or characters. When asked questions, she replies to one of the officers, "Who do you think you are, God, to decide who's good or not good to enter the New World?" Her reaction challenges the whole process and recalls Lucy's remark when she is interviewed by an officer before being permitted to enter the United States. When the immigration officer explains why the newcomers must submit to tests, Lucy questions herself the so-called "modern" American vision of the foreigners' intelligence. But, for the young men and women, America's doors are opened and the harbour of New York is the doorstep to the New World.

Therefore, in spite of the alienation that flows through the whole film, Crialese presents a positive image of the Ellis Island experience. In fact, the island could be associated with some happiness: newcomers once again had the chance to meet relatives or friends who had emigrated before them or who had sponsored them or future husbands that would secure them with a decent living (Brownstone 164). It seems to the newcomers that, after solitude and despair, and once the tests are passed, the New World is at hand. The immigration candidates could feel reassured that the system of chain migration worked and that the many ethnic enclaves dotting the country (the Little Italies) would welcome the newcomers.

Salvatore socializes with other Italians during the journey, both aboard the ship and on Ellis Island. This can be regarded as a romanticized view in the sense that, as the Italian nation had just been born, individuals from the peninsula had no nationalistic sentiment yet and did not feel any specific solidarity with other Italians (Cinel 10). As Salvatore states while on the ship, Italians did not know that people from other Italian regions were fellow citizens, and they did not even speak the same language. But in the film, they stick together, which is a way for Crialese to reduce the feeling of isolation. It can give an even more constructive image of the passage through the port of New York, from misery and solitude to hope and promise. 
During their processing in the centre, immigrants are introduced to some concrete elements that embody the American Dream. For example, they are given what the newcomers consider as "good food." Salvatore tastes white bread, which represents America as a land of plenty. Southern-European peasants were not used to eating white bread at home, and as soon as they reached the other side of the ocean, they had the opportunity to try new meals and products (DeSalvo 323). Even if Salvatore remarks that this white bread is tasteless, which surprises him, it seems that it brings to his mouth the taste of a new life. His neighbours even reply that it is a gift from God, which makes America an even more valuable place to which to emigrate. The myth of abundance attracted Europeans overseas, and this scene works as evidence of the riches that America has to offer. At the beginning of the film, when they are in their village, still vacillating between staying or leaving, the Mancusos come across some postcards sent from America. These postcards present overgrown vegetables_-for example, onions too big to fit in a wheelbarrow - and hens as big as ponies, which help them to make the decision to emigrate. These postcards display the representation that poor European villagers had of America, of all the promises of the New World that the Old World could not offer.

This idealistic image of America is underlined in a particular scene showing the characters swimming in a river of milk (Figure 15). These dreamlike scenes appear three times throughout the movie as a leitmotif to resurrect the promises that emigration encapsulates, and they stand in stark contrast with the scenes dealing with the miserable lives that the Mancusos led in Sicily in the film's first act.

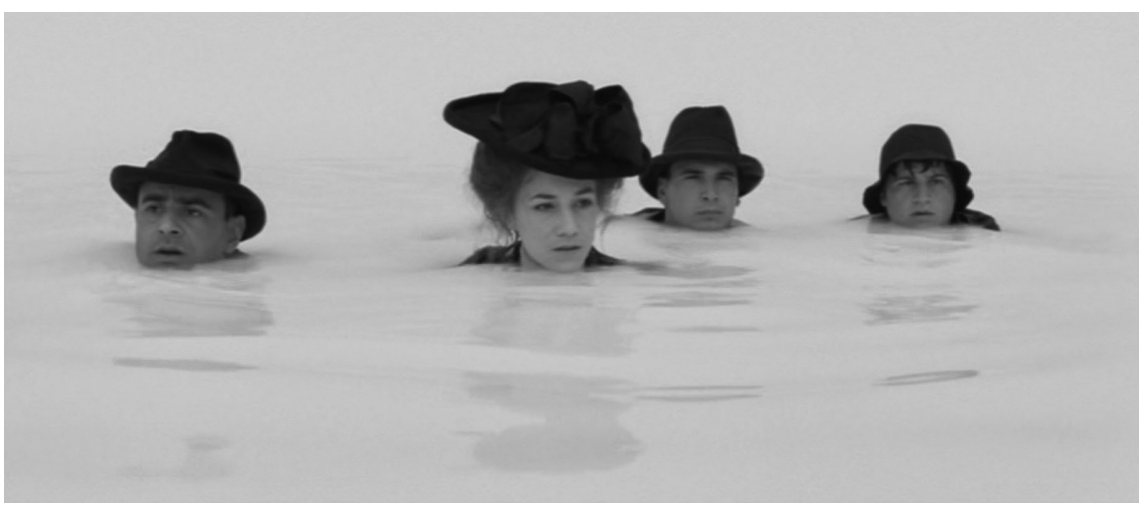

Figure 15. Courtesy of Memento Films 
The reference to the Bible is obvious, as we can read in Exodus, where abundance appears as a land full of milk and honey: "And I am come down to deliver them out of the hand of the Egyptians, and to bring them up out of that land unto a good land and a large, unto a land flowing with milk and honey" (Living Bible, Exodus 3:8). Such scenes highlight the hopes that are implied in the emigration process. They break with the narrative and realistic discourse of the movie because of their universal scope. The milk symbolizes the American Dream that is then reachable. The screen is full of milk; the characters are plunged into it as they will be plunged into the promises of the New World, its promises of happiness and freedom.

This idea is underlined by the extra-diegetic music of "Feelin' Good," by Nina Simone (1964), a song that originated in the narrative of slavery: "It's a new dawn / It's a new day / It's a new life for me and I'm feelin' good." Ironically, it refers here to the masses of immigrants who had come to toil in America and whose employment conditions are compared to those of Black slaves, who had expected to get much out of their freedom just as immigrants had expected to get much out of their settlement in America. But Italian migrants were often taken as "white niggers," since their exploitability kept them in an inferior social position comparable to that of former slaves (Vecoli 42; Jacobson 57). Thus, it seems that Simone is singing for the sake of African Americans but also on behalf of Italian migrants. Along with the song, the image of an ocean of white milk stands for the possibility of upward mobility. Therefore, Ellis Island is offering a new life, as it is the door to the New World. The song provides the film with a feeling of hope. This is an unexpected message, as Nuovomondo pinpoints the alienating experience that the passage through Ellis Island constituted, but, as a tribute to all the immigrants who showed bravery and persistence, the movie ends with a biblical image: they are accepted in the New World. The fact that the Mancuso family is then joined by an increasing number of immigrants who come to fill the screen as they swim in the ocean of milk testifies their belief in the United States as a Promised Land.

\section{Conclusion}

In spite of the fearful image that Ellis Island inspired and its corresponding association with deportation, the number of individuals processed in the centre and accepted to enter the United States was significant. Between 1892 and 
1924, the period of mass migration, more than 14.2 million people (71 percent of total immigration) were admitted to the United States through Ellis Island. Passing through this centre for processing actually represented a small obstacle to the arrival of Europeans. Even though the Mancusos are finally entitled to enter the New World, Nuovomondo delivers a cautionary tale of anti-immigrant prejudices and feelings as it focuses on the trauma that the process provoked. Simultaneously, the film rewards its characters in the end: after a long, tiring, and alienating journey from their village to the door of the New World, on this small island in front of the Statue of Liberty, thanks to their determination, courage, and hopeful vision of life, "the huddled masses yearning to breathe free" (to cite Emma Lazarus once more) are eventually admitted to the United States. Crialese wants to qualify the myth of the Promised Land by underlining the humiliating step that Ellis Island, the alleged Golden Door to "il Nuovomondo," represented. The very fact that America is never presented makes the audience, as well as the characters/immigrants, experience a feeling of unreachability, as if Crialese had wanted to challenge the myth of "il Nuovomondo" as a Promised Land.

\section{Works Cited}

Baily, Samuel L. Immigrants in the Lands of Promise: Italians in Buenos Aires and New York City, 1870-1914. Ithaca: Cornell UP, 1999.

Bible, Living Bible. Eastbourne: Kingsway Publications, 1987.

Brownstone, David M., Irene M. Franck, and Douglass Brownstone. Island of Hope, Island of Tears. New York: MetroBooks, 2002.

Carnevale, Nancy. A New Language, A New World: Italian Immigrants in the United States, 1890-1945. Chicago: U of Illinois P, 2009.

Cinel, Dino. The National Integration of Italian Return Migration, 1870-1929. Cambridge: Cambridge UP, 1991.

Daniels, Roger. Coming to America: A History of Immigration and Ethnicity in American Life. New York: Harper Perennial, 1990.

DeSalvo, Louise. "Cutting the Bread." In The Milk of Almonds. Italian American Women Writers on Food and Culture. Ed. Louise DeSalvo and Edvige Giunta. New York: Feminist Press at the CUNY, 2002. 
Foucault, Michel. "Des espaces autres." Architecture, Mouvement, Continuité 5 (Oct. 1984), 46-49.

. Surveiller et punir : Naissance de la prison. Paris: Gallimard, 1975.

Gabaccia, Donna. Women, Gender, and Transnational Lives. Toronto: U of Toronto $\mathrm{P}, 2002$.

Jacobson, Matthew Frye. Whiteness of a Different Color: European Immigrants and the Alchemy of Race. Cambridge: Harvard UP, 1998.

Kraut, Alan M. The Huddled Masses: The Immigrant in American Society, 1880 1921. Arlington Heights, IL: Harlan Davidson, 1982.

La Guardia, Fiorello H. The Making of an Insurgent. An Autobiography: 1882-1919. 1948. https://ia601508.us.archive.org/34/items/in.ernet. dli.2015.156112/2015.156112.The-Making-Of-An-Insurgent-An-Autobiography-1882-1919.pdf. 16 Feb. 2017.

Mangione, Jerre, and Ben Morreale. La Storia: Five Centuries of the Italian American Experience. New York: Harper and Collins, 1992.

Messina, Elizabeth. "Narratives of Nine Italian American Women: Childhood, Work and Marriage." Italian Americana 10.2 (Spring/Summer 1992): 186202.

Michaud, Marie-Christine. "Représentation du voyage transatlantique chez les migrants italiens. L'exemple de Golden Door de Emanuele Crialese.” In Entre Ciel et Mer. Le voyage transatlantique de l'Ancien au Nouveau Monde, XVIIeXXIe siècles. Ed. Marie-Christine and Philippe Hrodej. Rennes: Presses Universitaires de Rennes, 2014.

"New Immigration Station: Will be Ready for Use by Dec. 15". New York Times 3 Dec 1900, 5.

Reeves, Pamela. Ellis Island. Gateway to the American Dream. New York: Barnes and Noble Books, 2002.

Tomasi, Lidio. Images. A Pictorial History of Italian Americans. New York: Center for Migration Studies, 1986.

Vecoli, Rudolph. "The Italians.” In They All Chose America. Ed. Albert Q. Maisel. New York: T. Nelson Publisher, 1957. 